\title{
Prevalence of pain at the head, face and neck and its association with quality of life in general population of Piracicaba city, Sao Paulo: an epidemiological study*
}

\author{
Prevalência de dor no segmento cefálico e sua associação com qualidade de vida na \\ população geral do município de Piracicaba, São Paulo: um estudo epidemiológico
}

Marília Araújo Ruivo, Marcelo Corrêa Alves², Maria da Graça Rodrigues Bérzin³, Fausto Bérzin ${ }^{1}$

${ }^{*}$ Received from School of Dentistry of Piracicaba, State University of Campinas, Piracicaba, SP, Brazil.

DOI 10.5935/1806-0013.20150004

\section{ABSTRACT}

BACKGROUND AND OBJECTIVES: Head, face and neck pain affects a large portion of the world population, however there are few studies reporting this condition in general Brazilian population. This study aimed at investigating the prevalence of head, face and neck pain and its impact on the quality of life of adults of Piracicaba city, São Paulo.

METHODS: The sample was made up of 400 volunteers of both genders, aged between 20 and 50 years, who were randomly approached in six crossing points of the city. Socio-demographic, pain prevalence, location, frequency, duration and severity, and self-perception of quality of life data were collected by means of anonymous self-applied questionnaires: Orofacial Pain Questionnaire and WHOQOL-BREF.

RESULTS:Pain prevalence was $54.75 \%$, of predominantly severe intensity $(21.30 \%)$, daily recurrence $(41.10 \%)$ and present for more than six months $(91.32 \%)$. Most affected region was the head $(36 \%)$ being the intraoral region the less frequently reported $(6 \%)$. There has been no significant association between pain and factors such as age, economic level and education ( $p>0.05)$; however there has been significant prevalence among females. No pain was frequently associated to better quality of life $(\mathrm{p}<0.05)$. Volunteers reporting pain were more unhappy with quality of sleep $(\mathrm{p}<0.05)$, however there has been no significant association with the frequency of negative feelings.

1. State University of Campinas, School of Dentistry of Piracicaba, Piracicaba, SP, Brazil.

2. University of Săo Paulo, Piracicaba, SP, Brazil.

3. Clinical Center of Piracicaba, Piracicaba, SP, Brazil.

Submitted in September 29, 2014.

Accepted for publication in February 19, 2015.

Conflict of interests: none - Sponsoring sources: CAPES.

Correspondence to:

Marília Araújo Ruivo

Av. Limeira, 901

13414-903Piracicaba, SP, Brasil.

E-mail: marilia_ruivo@hotmail.com

(C) Sociedade Brasileira para o Estudo da Dor
CONCLUSION: The study has identified high prevalence of head, face and neck pain, significant morbidity of people affected by this condition and its negative impact on quality of life. Keywords: Chronic pain, Epidemiology, Prevalence, Quality of life.

\section{RESUMO}

JUSTIFICATIVA E OBJETIVOS: As dores que acometem o segmento cefálico afetam grande parte da população mundial, porém são poucos os trabalhos que retratam essa condição na população geral do Brasil. O objetivo deste estudo foi investigar a prevalência de dor no segmento cefálico e seu impacto sobre a qualidade de vida de adultos do município de Piracicaba, Sáo Paulo.

MÉTODOS: A amostra foi composta por 400 voluntários de ambos os gêneros, com idade entre 20 e 50 anos que foram aleatoriamente abordados em seis pontos de passagem do município. A coleta de dados sócio-demográficos, prevalência, localização, frequência, duração, gravidade da dor e autopercepção da qualidade de vida foi realizada por meio de questionários anônimos autoaplicados, o Questionário de Dor Orofacial e o WHOQOLBREF.

RESULTADOS: A prevalência de dor foi de 54,75\%, de intensidade predominantemente intensa $(21,30 \%)$, recorrência diária $(41,10 \%)$ e presente há mais de seis meses $(91,32 \%)$. A região mais acometida foi a cabeça (36\%) sendo a região intraoral menos frequentemente apontada (6\%). Não se observou associação significativa entre a presença de dor e fatores como idade, nível econômico e escolaridade ( $p>0,05)$, porém houve significativa prevalência de dor entre as mulheres. A ausência de dor foi frequentemente associada à melhor qualidade de vida $(\mathrm{p}<0,05)$. Voluntários que relataram dor apresentaram maior insatisfação com a qualidade do sono $(\mathrm{p}<0,05)$, porém não foi observada associação significativa com a frequência de sentimentos negativos. CONCLUSÁO: O estudo identificou alta prevalência de dor no segmento cefálico, significante morbidade das pessoas acometidas por essa condição e seu impacto negativo sobre a qualidade de vida.

Descritores: Dor crônica, Epidemiologia, Prevalência, Qualidade de vida. 


\section{INTRODUCTION}

Epidemiology may be defined as the "study of distribution and determinants of health-related states or events in specific populations and the application of this study to control health problems". Epidemiological studies in the area of pain are important because they provide information about its prevalence in different population segments and about factors associated to its etiology and persistence, being very useful for health professionals and for the development of pain-fighting programs ${ }^{2}$.

Currently being considered a severe public health problem, pain, the prevalence of which is growing, is the primary reason for the search for health assistance by the general population ${ }^{3}$.

Among most frequent pain complaints there are those in head, face and neck ${ }^{4}$, the so-called orofacial pains (OFP), which may affect head, face and neck soft and hard tissues. $5^{5}$ Population studies have shown that the prevalence of oral complex and craniofacial pain is high, affecting approximately one fourth of the population at least once in life ${ }^{6}$.

OFP may be classified in different ways. One of them differentiates acute from chronic pain. Acute pain is commonly associated to toothache and periodontal pain. Persistent or chronic pain is more frequent in temporomandibular disorders and idiopathic facial pain ${ }^{7}$.

Epidemiological surveys in the United States, Canada and United Kingdom have observed that the frequency of OFP in general adult population may vary from 14 to $40 \%{ }^{8-11}$. Epidemiological studies with the Brazilian population refer a variation of 32.2 to $73.1 \%$ in OFP frequency, especially chronic OFP, depending on evaluated conditions and methodologies used ${ }^{12-15}$.

When pain persists and become chronic it may negatively impact quality of life (QL). Pain becomes the primary focus of patients' attention, may produce physiological disorders, change emotional balance and cause social and professional losses such as sleep disorders, physical and emotional fatigue, loss of social contact, difficulty to eat, daily life activities limitation and absenteeism at work ${ }^{16}$. In the dental area, individuals affected by OFP suffer major changes in their daily activities, among them, dissatisfaction with oral condition, drug ingestion and dietary changes, which may affect QL more than other systemic conditions such as diabetes, hypertension or ulcer ${ }^{17}$.

The high prevalence of head, face and neck pain and its negative repercussions on QL of individuals have been the focus of public health investigations, due to the morbidity that may be caused by such conditions. However, notwithstanding the relevance of such symptoms, Brazilian epidemiological studies involving the general population are still scarce and most of them use convenience samples such as populations linked to treatment clinics or assistance units, which makes difficult the establishment of social and health policies prioritizing and making feasible adequate prevention and treatment, minimizing health costs and especially the distress of those suffering pain, especially chronic pain.

So, this study aimed at estimating the prevalence and characteristics of head, face and neck pain in the general adult population of the city, and at correlating them to health and QL selfperception.

\section{METHODS}

This is a cross-sectional and observational study with the adult population of the city of Piracicaba, Sáo Paulo. Participated in the study 400 volunteers of both genders (200 males and 200 females), aged between 20 and 50 years (mean of 34.70 years and standard deviation of 8.75 years), coming from 68 districts of the city and who were randomly addressed in six crossing points of the city with major population movement. Sample size was calculated as from the official city population, or 385,287 inhabitants (Source: Brazilian Institute of Geography and Statistics, 2013 $)^{18}$, with confidence level of $95 \%$ and confidence interval of 5\%, calculated by the Sample Size Calculator ${ }^{19}$.

Data on OFP prevalence and characteristics and QL selfperception were collected by means of two structured, standardized and pre-tested anonymous and self-applied questionnaires: Orofacial Pain Questionnaire and Quality of Life Evaluation questionnaire WHOQOL-BREF.

This study is integral part of the research project "Epidemiological study of orofacial pain and correlation with health and QL in the general population of the Brazilian South-Eastern region", and was carried out in compliance with ethical principles of the declaration of Helsinki and Resolution 196/96 of the National Health Council.

\section{Orofacial pain questionnaire}

Developed by the authors, with no intention of being a diagnostic tool, the questionnaire is made up of questions aiming at sample demographic characterization (gender, age, education level, economic condition, district of residence), six questions to evaluate the presence of OFP and, when present, pain characteristics (pain site, frequency, duration, intensity and location according to head and neck topographic anatomic regions), one question related to recent head, neck or jaw traumas, drug consumption, treatments and the presence of systemic disease. An Economic Classification Index (ECI) was developed based on the sum of points attributed according to answers to some questions. Those who did not receive government benefits received 10 points, those with their own home 20 points, if the home was already paid 20 additional points and if it was financed only 10 points. If their home had a swimming-pool, 40 points and if the person had access at home to broadband Internet, 10 points. According to calculations, a volunteer may receive a score varying from zero (with government benefit, without access to broadband Internet, without own home and without swimming-pool in the house they lived) up to 100 (no government benefit, with own home paid and with swimming-pool, and with access to broadband Internet).

All volunteers were classified according to described criteria and afterward the classification was made in quartiles.

\section{Quality of life evaluation questionnaire (WHOQOL- BREF)}

Validated for Brazil, the questionnaire is made up of 26 questions which quantify QL perception according to four do- 
mains: physical, psychological, social relations and environment. A score varying from zero to 100 was used for analysis of results, being considered three QL levels: good - 75 to 100 points; indifferent -50 to 75 points and poor -25 to 50 points $^{20}$.

\section{Data collection}

Questionnaires were applied in six different crossing points selected for allowing the approaching of people of different socio-economic levels, age and gender and from all regions of the city: Central Terminal of Urban Buses System Integration, School of Dentistry of Piracicaba, squares, traditional commercial areas, Shopping Malls and Intermunicipal Bus Station. Volunteers approached at the School of Dentistry of Piracicaba did not include patients being treated in the institution's graduation or post-graduation clinic, but rather employees of the institution and escorts of dentistry clinic patients.

Individuals were randomly approached and invited to participate in the research. In case of acceptance, study objectives and methods were clearly presented in writing. After reading and signing the Free and Informed Consent Term (FICT), Orofacial Pain Questionnaire was applied, followed by the Quality of Life Evaluation Questionnaire. If there was no pain, volunteers were oriented to answer questions for sociodemographic evaluation and were then asked to answer the WHOQOL-BREF questionnaire.

Data collection was standardized and carried out only in the morning, approaching individuals before going to work, such as in the Central Integration Terminal and squares. Employees of the School of Dentistry of Piracicaba, Shops and Intermunicipal Bus Station were approached before beginning of the work day to prevent tiredness built-up during the work day and which could influence answers.

\section{Statistical analysis}

Data were analyzed by the statistical program SAS21. Univariate contingency tables and correlated Chi-square tests for proportions equality test were built. Two-dimension contingency tables were built to study the existence of association among variables. Cochram, Mantel and Haenszel test was applied to correlate answers scores in different levels of variables adopted as factors. Additionally, Odds ratio was calculated. To test the existence of association among variables used to build two-dimension tables, Mantel and Haenszel Chi-square test was used for ordinal factors and Wald test was used for nominal factors. Significance level for all tests was $5 \%(\alpha=0.05)$.

This study was approved by the Research Ethics Committee under protocol 094/2010 - UNIFAL-MG.

\section{RESULTS}

From a total of 400 participants, 200 (50\%) were females and $200(50 \%)$ were males, with mean age of 34.7 years. As to education level, only two volunteers $(0.50 \%)$ have stated having no education. Approximately half the volunteers had completed high school (49.75\%), while 106 (26.63\%) had stated having incomplete high school and $92(23.12 \%)$ had finished college. Mean ECI was 41.23 with prevalence of quartile 3 made up of 190 volunteers (47.50\%), followed by quartile 2 with 97 people $(24.25 \%$ ), quartile 1 with 83 volunteers $(20.75 \%)$ and quartile 4 corresponding to $7.50 \%$ of the sample, or 30 volunteers (Table 1 ).

Observed head, face and neck pain of $54.75 \%$ had no statistically significant difference $(\mathrm{p}=0.0574)$, with predominantly severe intensity $(21.30 \%)$, daily frequency $(41.10 \%)$ and lasting for more than six months $(91.32 \%)$, being head the region most commonly indicated (36\%), followed by shoulders (22.25\%), face $(20.00 \%)$, neck $(19.25 \%)$, teeth $(9.50 \%)$ and intraoral region (6\%) (Table 2).

Aiming at checking pain prevalence indices variation according to gender, age, education level and economic condition variables, Cochram, Mantel and Haenszel test was applied to the first variable and Wald Chi-square test was applied to remaining variables (Table 3). There has been no statisti-

Table 1. Frequency and percentage of socio-demographic data and Chi-square test $p$-value for equality of proportions

\begin{tabular}{|c|c|c|c|c|}
\hline Factors & Categories & Frequency (n) & Percentage (\%) & $\mathrm{p}$-value \\
\hline \multirow[t]{2}{*}{ Gender } & Male & 200 & 50.00 & 1.0000 \\
\hline & Female & 200 & 50.00 & \\
\hline \multirow[t]{3}{*}{ Age (years) } & $20-30$ & 132 & 33.00 & 0.9200 \\
\hline & $30-40$ & 137 & 34.25 & \\
\hline & $40-50$ & 131 & 32.75 & \\
\hline \multirow[t]{4}{*}{ Education } & No education & 2 & 0.50 & 0.0001 \\
\hline & Incomplete high & 106 & 26.63 & \\
\hline & Complete high & 198 & 49.75 & \\
\hline & College & 92 & 23.12 & \\
\hline \multirow[t]{4}{*}{ Economic condition } & Quartile 1 & 83 & 20.75 & 0.0001 \\
\hline & Quartile 2 & 97 & 24.25 & \\
\hline & Quartile 3 & 190 & 47.50 & \\
\hline & Quartile 4 & 30 & 7.50 & \\
\hline
\end{tabular}


Table 2. Frequency and percentage of orofacial pain classifications reported by volunteers and p-value of Chi-square test for equality of proportions

\begin{tabular}{|c|c|c|c|c|c|}
\hline Pain characteristics & Category & Frequency (n) & \multicolumn{2}{|c|}{ Percentage (\%) } & $\mathrm{p}$-value \\
\hline \multirow[t]{2}{*}{ Presence } & Yes & 219 & \multicolumn{2}{|c|}{54.75} & 0.0574 \\
\hline & No & 181 & \multicolumn{2}{|c|}{45.25} & \\
\hline \multirow{3}{*}{ Frequency } & Weekly & 51 & 23.29 & $\mathrm{~b}$ & \\
\hline & Seldom & 34 & 15.53 & $\mathrm{bc}$ & \\
\hline & Fortnightly & 14 & 6.39 & $d$ & \\
\hline \multirow[t]{3}{*}{ Chronicity } & Chronic & 200 & 91.32 & $\mathrm{a}$ & 0.0001 \\
\hline & Acure & 6 & 2.74 & $\mathrm{~b}$ & \\
\hline & Sub-acute & 13 & 5.94 & $\mathrm{~b}$ & \\
\hline \multirow[t]{2}{*}{ Intensity } & Absent & 181 & 45.36 & a & 0.0001 \\
\hline & Mild & 28 & 7.02 & c & \\
\hline \multirow[t]{6}{*}{ Location } & Head & 144 & 36.00 & $\mathrm{a}$ & 0.0001 \\
\hline & Shoulders & 90 & 22.25 & $b$ & \\
\hline & Face & 89 & 20.00 & $\mathrm{~b}$ & \\
\hline & Neck & 77 & 19.25 & $b$ & \\
\hline & Teeth & 38 & 9.50 & $c$ & \\
\hline & Inside mouth & 24 & 6.00 & c & \\
\hline
\end{tabular}

Percentages with equal letters are not different among them in a same characteristic by Chi-square test $(\alpha=0.05)$.

Table 3. Distribution of orofacial pain self-perception according to gender, age, education level and economic condition

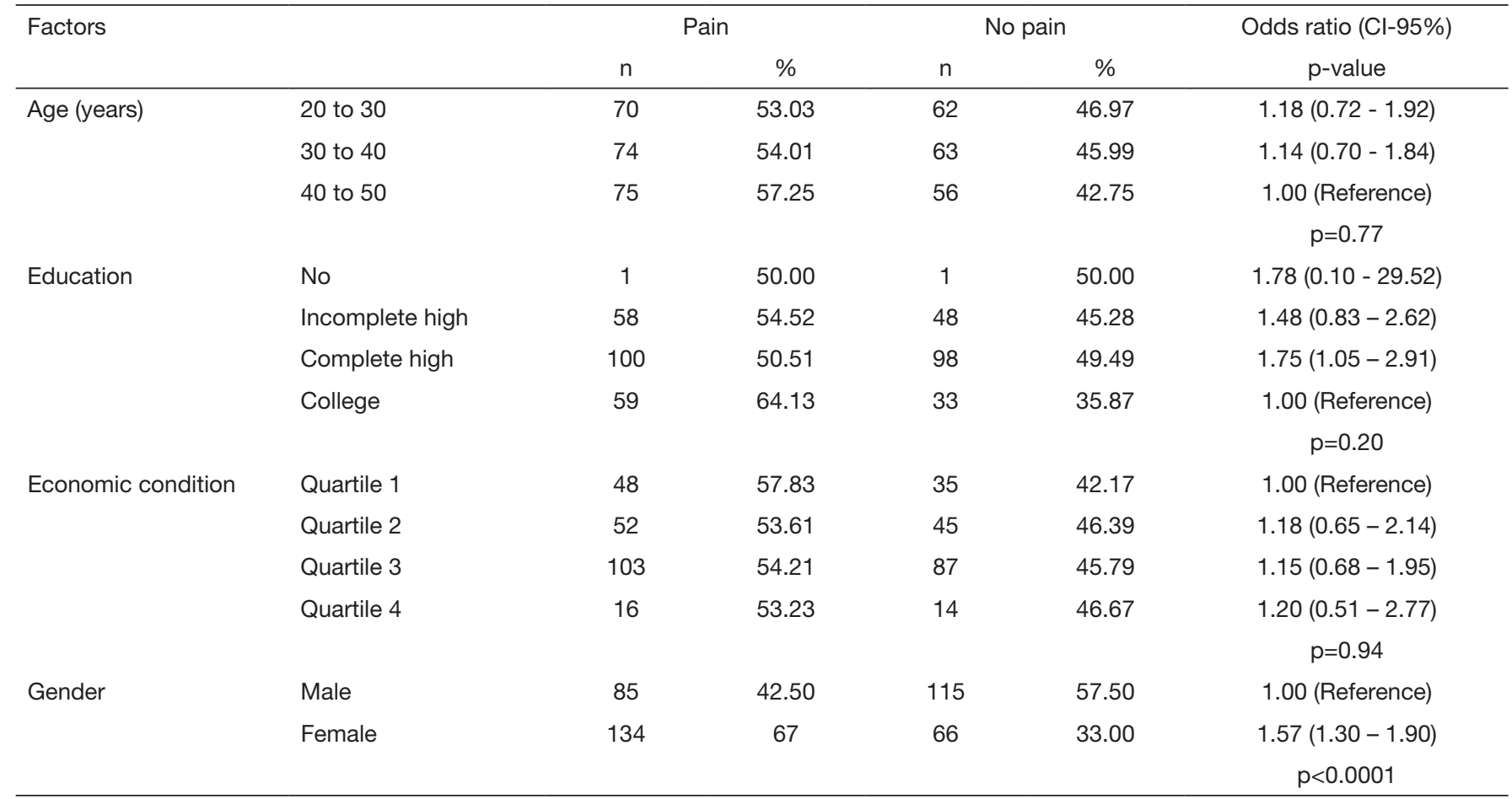

$\mathrm{p}$ value calculated from the test Cochran, Mantel and Haenszel and to the variable "gender" and Wald Chi-square for the other and statistical odds ratio. 
cally significant difference between pain prevalence and age $(p=0.77)$, education level $(p=0.30)$ and economic condition $(\mathrm{p}=0.94)$; however, the study has observed higher frequency of pain reports by females $(\mathrm{p}<0.0001)$. Odds ratio analysis suggests a risk 1.57 times higher of females having head, face and neck pain as compared to males, however there has been no evidence that individuals of a certain age group, education level or specific economic condition would be at higher risk to develop OFP.

Mantel and Haenszel Chi-square test provides sound evidences $(\mathrm{p}<0.01)$ of a linear association between pain and QL and sleep quality self-perception, so that it is less probable to be happy with sleep or to report a good QL when there is pain (Tables 4 and 5). Pain intensity was also linearly associated to QL self-perception ( $\mathrm{p}=0.0002)$ (Table 4). However, there has been no significant association between frequency of negative feelings, such as depression, anxiety, bad mood, despair and OFP reports $(\mathrm{p}=0.11)$ (Table 6$)$.

\section{DISCUSSION}

Our study describes a general scenario about biopsychosocial characteristics of the general adult population of the city of Piracicaba with regard to head, face and neck pain.

Although not having a statistically significant frequency, one may state that OFP is a highly prevalent condition in the studied sample $(54.75 \%)$. This result has clinical biological importance because more than half the adult population of the city has pain, with predominantly severe $(21.30 \%)$ and moderate $(16.04 \%)$ intensity, often daily (41.10\%) and lasting for more than six months (91.32\%), in addition to being higher than values presented by other studies with different populations s $^{11,22,23}$.

Females have reported more pain (67\%), which is in line with the literature ${ }^{11,14,24,25}$, however without emphasis on age group, education level or economic condition. Sev-

Table 4. Quality of life self-perception according to WHOQOL-BREF in groups with and without orofacial pain and quality of life level with regard to pain intensity

\begin{tabular}{|c|c|c|c|c|c|c|c|}
\hline \multirow[t]{2}{*}{ Groups } & \multicolumn{2}{|c|}{ Good } & \multicolumn{2}{|c|}{ Indifferent } & \multicolumn{2}{|c|}{ Poor } & \multirow[t]{2}{*}{$\mathrm{p}$-value } \\
\hline & $\mathrm{n}$ & $\%$ & $\mathrm{n}$ & $\%$ & $\mathrm{n}$ & $\%$ & \\
\hline With pain & 48 & 21.92 & 147 & 67.12 & 24 & 10.96 & 0.0001 \\
\hline Mild pain & 8 & 28.57 & 18 & 64.29 & 2 & 7.14 & 0.0002 \\
\hline Moderate pain & 17 & 26.56 & 43 & 67.19 & 4 & 6.25 & \\
\hline Unbearable pain & 9 & 21.95 & 22 & 53.66 & 10 & 24.39 & \\
\hline
\end{tabular}

p-value calculated as from Mantel and Haenszel Chi-square test.

Table 5. Prevalence of sleep quality indicators in volunteers with and without orofacial pain according to WHOQOL-BREF

\begin{tabular}{|c|c|c|c|c|}
\hline & & With pain & Without pain & $p$-value \\
\hline \multirow{5}{*}{$\begin{array}{l}\text { Sleep quality indicators } \\
\text { (16) }\end{array}$} & Very unhappy & $25(92.95 \%)$ & $2(7.41 \%)$ & \multirow[t]{5}{*}{$<0.0001$} \\
\hline & Unhappy & $34(72.34 \%)$ & $13(27.66 \%)$ & \\
\hline & Neither happy nor unhappy & $55(58.51 \%)$ & $39(41.49 \%)$ & \\
\hline & Happy & $81(49.39 \%)$ & $83(50.61 \%)$ & \\
\hline & Very happy & $24(35.29 \%)$ & $44(64.71 \%)$ & \\
\hline
\end{tabular}

Table 6. Prevalence of negative feelings in volunteers with and without orofacial pain, according to WHOQOL-BREF

\begin{tabular}{llccc}
\hline & & With pain & Without pain & p-value \\
\hline Frequency of negative & Never & $25(11.42 \%)$ & $38(21.11 \%)$ & 0.11 \\
feelings (26) & Sometimes & $124(56.62 \%)$ & $97(53.89 \%)$ \\
& Often & $38(17.35 \%)$ & $29(16.11 \%)$ \\
& Very often & $17(7.76 \%)$ & $9(5.00 \%)$ \\
& Always & $15(6.85 \%)$ & $7(3.89 \%)$ \\
\hline
\end{tabular}


eral studies have observed variability on pain prevalence in different age groups, however it is worth stressing that samples were made up of young and elderly people $e^{9,11,14,23}$, while our sample was made up only of adults. However, other authors have also not identified this association ${ }^{6,26}$. With regard to social aspects, it is possible to observe in the literature discrepant results of OFP prevalence related to education and economic levels. In this aspect, it is worth highlighting difficulties to define and measure different socioeconomic levels in general, which suggests that such factors have secondary importance for the development of this painful condition ${ }^{27}$.

With regard to head, face and neck pain severity, observed prevalence of severe and moderate pain is similar to what was found by other authors ${ }^{6,28}$. The fact that more than one fifth of the sample has referred severe pain suggests that a considerable portion of adults living in the city have important morbidity associated to OFP. Other aspect reinforcing such condition is related to pain frequency. Almost half the individuals reporting OFP suffer this condition every day. Results are in line with an OFP study, carried out in Spain ${ }^{29}$ with patients of a health center in Cordoba, whose most recurrent answers were: "quite often and "very often". Such comparison highlights the clinical importance of results observed among residents of the city of Piracicaba, who referred pain frequency similar to patients under pain treatment of the above-mentioned study.

Most prevalent pain was headache $(36.00 \%)$, followed by shoulders $(22.5 \%)$, face $(20.00 \%)$, neck $(19.25 \%)$, teeth $(9.50 \%)$ and intraoral region $(6.00 \%)$. Few are the studies investigating head, face and neck pain frequency present in $\mathrm{OFP}^{15,32}$. Some of them point to higher prevalence of toothache as compared to joint or facial pain, or burning mouth ${ }^{6,13,14,26}$. However, our study has observed higher prevalence of chronic headache, result also observed by other authors ${ }^{15,30}$. It is possible that the low prevalence of toothache may be associated to preventive measures for the development of tooth decay (major responsible for pulp toothache) carried out in the city, with broad fluoridation of water that reaches homes, in addition to easy access to public dental assistance services specialized in toothache.

The same is not true for the access of the population to specialized head, face and joint pain. The city has 241 health assistance units, however the general academic qualification of dentists and physicians has indicators of theoretical-technical deficiencies in the area of pain ${ }^{31}$, making difficult the effective diagnostic and therapeutic practice in the assistance of OFP individuals.

Our results also confirm the association of OFP, especially chronic, and the negative impact on QL functional, social and psychological aspects, ${ }^{6,12-15,22,23,29,33}$. Pain has a major impact on QL of people, due to suffering and daily life limitations, which generates severe effects for individuals themselves and also for society, such as high costs of specialized treatment and hours lost in the productive process ${ }^{11}$, as well as sleep quality impairment ${ }^{34}$. Pain intensity was also associated to higher frequency of negative reports on QL level. Individuals referring no pain or mild pain had higher WHOQOL means as compared to those reporting severe or unbearable pain. According to other authors ${ }^{29,35}$, pain intensity is a major QL determinant among all other OFP characteristics, such as number of symptoms, frequency and duration, deserving attention from the professional when treating patients with such painful condition.

We have not identified statistically significant meaning in the association between frequency of negative feelings, such as bad mood, despair, anxiety and depression, and the presence or not of pain, as also observed by a different study ${ }^{26}$, which highlights the subjectivity of the meaning individuals give to pain with regard to other QL aspects evaluated by the WHOQOL-BREF questionnaire and to the fact that, although there is sound evidence that chronic pain may be related to physical disability, emotional disorders and social difficulties, these are not universal phenomena and although some people become physically disabled, others adapt well to chronic pain by means of effective pain coping strategies ${ }^{36}$. In addition, it is not possible to establish, by means of a cross-sectional study, whether the same feelings are result of OFP. However, results point to the importance of recognizing the presence of such feelings in people referring pain and who might need specialized treatment.

Some limitations should be taken into consideration when interpreting the results of this study, which were based on self-reports about pain symptoms, without clinical evaluation of volunteers. However, we believe in the fidelity of volunteers' reports, which does not necessarily affects results. WHOQOL-BREF questionnaire, used to evaluate $\mathrm{QL}$, is an already established research tool in the clinical practice for supplying important indicators obtained as from the analysis of different domains. So, results indicate association between OFP and poor QL perception, although one cannot establish a direct causality relationship between both factors.

\section{CONCLUSION}

The study has observed high prevalence of head, face and neck pain in general adult population of the city of $\mathrm{Pi}$ racicaba, predominantly severe to moderate pain, daily frequency and lasting for more than six months. Results point to the need for health policies developed based on explanation, education, prevention and control of pain, which significantly affects QL of the population.

\section{ACKNOWLEDGMENTS}

Research financing: this study was financed by the Coordination of University Level Personnel Improvement (CAPES). 


\section{REFERENCES}

1. Last R. A Dictionary of Epideimiology, $4^{\text {th }}$ ed. Oxford: International Epidemiological Association; 2001.

2. Hecke O, Torrance N, Smith BH. Chronic pain epidemiology and its clinical relevance. Br J Anaesth. 2013;111(1):13-8.

3. Schappert SM, Burt CW. Ambulatory care visits to physician offices, hospital outpatient departments, and emergency departments: United States, 2001-2. National Center for Health Statistics. Vital Health Stat. 2006;13(159):1-66.

4. Sessle BJ. Acute and chronic craniofacial pain: brainstem mechanisms of nocicepyive transmission and neuroplasticity, and their clinical correlates. Crit Rev Oral Biol Med. 2000;11(1): 57-91.

5. De Rossi SS. Orofacial pain: a primer. Dent Clin N Am. 2013;(57):383-92.

6. McMillan AS, Wong MC, Zheng J, Lam CL. Prevalence of orofacial pain and treatment seeking in Hong Kong Chinese. J Orofac Pain. 2006;20(3):218-25.

7. LeResche L. Epidemiology of orofacial pain. In: Lund JP, Lavigne GJ, Dubner R, Sessle BJ, editors. Orofacial pain: from basic science to clinical magement. Chicago: Quintessence Publishing Company; 2001.

8. Locker D, Grushka M. Prevalence of oral and facial pain and discomfort: preliminary results of a mail survey. Community Dent Oral Epidemiol. 1987;15(3):169-72.

9. Lipton JA, Ship JA, Larach-Robinson D. Estimated prevalence and distribution of reported orofacial pain in the United States. J Am Dent Assoc. 1993;124(10):115-21.

10. Riley JL 3rd, Gilbert GH. Orofacial pain symptoms: an interaction between age and sex. Pain. 2001;90(3):245-56.

11. Macfarlane TV, Blinkhorn AS, Davies RM, Kincey J, Worthington HV. Oro-facial pain in the community: prevalence and associated impact. Community Dent Oral Epidemiol. 2002;30(1):56-60.

12. Michel-Crosato E, Biavenic MG, Nardi A, Crosato E. Relação entre dor orofacial e qualidade de vida: um estudo em trabalhadores. UFES Rev Odontol. 2006;8(2):45-52.

13. Lacerda JT, Ribeiro JD, Ribeiro DM, Traeber J. Prevalência de dor orofacial e seu impacto no desempenho diário em trabalhadores das indústrias têxteis do município de Laguna, SC. Ciênc Saúde Coletiva. 2011;16(10):4275-82.

14. Silva SR, Leite MC, Ferraz MA, Silva MF, Sousa YT. Dor orofacial e qualidade de vida em adultos. Odontol Bras Central. 2012;21(56):401-5.

15. De Siqueira SR, Vilela TT, Florindo AA. Prevalence of headache and orofacial pain in adults and elders in a Brazilian community: an epidemiological study. Gerodontology. 2013;1-9. [Epub ahead of print]

16. Teixeira MJ. Dor e depressão. Rev Neurociência. 2006;14(2):44-53.

17. Biazevic MG, Araújo ME, Michel-Crosato E. Indicadores de qualidade de vida relacionados com a saúde bucal: revisão sistemática. Rev Odontol . 2002;14(1):13-25

18. IBGE. Instituro Brasileiro de Geografia e Estatística. [acesso em 2 de janeiro de 2014]. Disponível em: http://www.cidades.ibge.gov.br/xtras/perfil.php?lang=\&codmun=353870

19. Creative Research System. Sample Size Calculator (2012). Creative Research System, Lone Oak:CA:EUA. [acessado em 10 de stembro de 2013]. Disponível em http:// www.surveysystem.com/sscalc.htm.

20. WHOQOL, World Health Organization. Measuring Quality of Life. The World health Organization quality of life instruments. Geneva: World Health Organization, 1997.

21. SAS Institute Inc. The SAS System, release 9.3. SAS Institute Inc., Cary:NC; 2012

22. Nuttal NM, Steele JG, Pine CM, White D, Pitts NB. The impact of oral health on people in the UK in 1998. Br Dent J. 2001;190(3):121-6.

23. Kohlmann T. Epidemiology of orofacial pain. Schmerz. 2002;16(5):339-45.

24. Riley JL 3rd, Gilbert GH, Heft MW. Orofacial pain symptom prevalence: selective sex differences in the elderly? Pain; 1998;76(1-2):97-104

25. Macfarlane TV, Blinkhorn AS, Davies RM, Kincey J, Worthington HV. Association between female hormonal factors and oro-facial pain: study in the community. Pain. 2002;97(1-2):5-10.

26. Leung WS, McMillan AS, Wong MC. Chronic orofacial pain in southern Chinese people: experience, associated disability, and help-seeking response. J Orofac Pain 2008;22(4):323-30

27. Tickle M, Craven R, Worthington HV. A comparison of the subjective oral health status of older adults from deprived and affluent communities. Community Dent Oral Epidemiol. 1997;25(3):217-22.

28. Wong MC, McMillan AS, Zheng J, Lam CL. The consequences of orofacial pain symnptoms: a population-based study in Hong Kong. Community Dent Oral Epidemiol. 2008;36(5):417-24

29. Blanco-Aguilera A, Blanco-Hungría A, Biedma-Velázquez L, Serrano-Del-Rosa R, González-López L, Blanco-Aguilera E, et al. Application of an oral health-related quality of life questionnaire in primary care patients with orofacial pain and temporomandibular disorders. Med Oral Patol Oral Cir Bucal. 2013;19(2):e127-35.

30. Beghi E, Monticelli ML, Amoruso L, Zarrelli MM. Prevalence, characteristics, and patterns of health care use for chronic headache in two areas of Italy. Results of a questionnaire interview in general practice. Cephalgia. 2003;23(3):175-82.

31. Bérzin MG, Siqueira JT. Study on the training of Brazilian dentists and physicians who treat patients with chronic pain. Braz J Oral Scien. 2009;8(1):44-9.

32. Agerberg G, Bergenholtz A. Craniomandibular disorders in adult populations of West Bothnia, Sweden. Acta Odontol Scand. 1989;47(3):129-40.

33. Kuroiwa DN, Marinelli JG, Rampani MS, de Oliveira W, Nicodemo D. Desordens temporomandibulares e dor orofacial: estudo da qualidade de vida medida pelo Medical Study 36 - Item Short Form Health Survey. Rev Dor. 2011;12(2):93-8.

34. Riley JL 3rd, Benson MB, Gremillion HA, Myers CD, Robinson ME, Smith CL, et al. Sleep disturbance in orofacial pain patients: pain-related or emotional distress? Cranio. 2001;19(2):106-13.

35. Zheng J, Wong MC, Lam CL. Key factors associated with oral healyh-related quality of life (OHRQOL) in Hong Kong Chinese adults with orofacial pain. J Dent. 2011:39(8):564-71.

36. Sardá Júnior JJ, Nicholas M, Pimenta CA. Validaçấo do Questionário de Incapacidade Roland Morris para dor em geral. Rev Dor. 2012;11(1):28-35. 